\title{
Morphological Traits Among the Enset (Ensete Ventricosum) Landraces and Cultural Use of the Landraces for the Livelihood of People in Southern Ethiopia
}

Wondimagegnehu Tekalign ( $\sim$ wondimagegnehubeyene@gmail.com )

Wolaita Sodo University

\section{Newarinesh Feleke}

Wolaita Sodo University

\section{Research Article}

Keywords: Conservation, Diversity, Abundant landraces, Ethnobotany, Diversity challenges

Posted Date: July 15th, 2021

DOI: https://doi.org/10.21203/rs.3.rs-688705/v1

License: (c) (i) This work is licensed under a Creative Commons Attribution 4.0 International License. Read Full License 


\section{Abstract}

\section{Background}

Ensete ventricosum is an important food crop consumed in the form of Bulla and Kocho mainly used in the southern parts of Ethiopia for their sustainable livelihood and ensuring food security. Besides, it is used as animal feed, as well as a source of medicine and fiber. This study was undertaken on the morphological traits among the Enset (Ensete ventricosum) landraces and cultural use of the landraces for the livelihood of people in Mareka woreda, Dawro zone, southern Ethiopia. The study was carried out in purposively selected four kebeles of Mareka district's Dawro zone.

Results

A total of 145 (20 purposively selected key informants and 125 randomly selected respondents) were interviewed using semi-structured interviews, and field observation was also used to collect ethnobotanical data. The morphological traits were measured according to IBPGR (International Board for Plant Genetic Resources) descriptors for Enset. The data were analyzed by using computer software SPSS v 16.0 as well as Excel 2010 spreadsheet. A total of 33 Enset landraces were identified from the study area. Farmers gave the name for their landraces based on the morphological trait and sources of planting material. Identified landraces were grouped into five clusters based on their morphological trait variability. Mean plant height, pseudostem height, and circumference, leaf size, and numbers have significant differences among clusters. Cluster number five had the highest mean in plant height, pseudostem height, and circumference and cluster number three had the lowest mean. The highest landrace richness was recorded from Ocha (3.18) while the lowest was from Guta (2.56). The most abundant landraces were Amiya, Hoeya, Boza, Yaka, Bothena, Ontha, Adinona, Shasha, and Keteriya in the Mareka district.

\section{Conclusions}

This study confirmed that the Dawro zone is rich in diversity of Enset, however, reduction in production and loss of some landraces was observed because of different factors. Therefore, attention must be given to the conservation and maintenances of Enset landraces by all the concerned bodies.

\section{Introduction}

Root and tubers are plants yielding starchy roots, tuber, rhizomes, corms, and stems. They are used mainly for human food, animal feed and, the manufacturing of starch, and alcohol including beer (Hildebrand 2001). Enset (Ensete ventricosum) is one of the root crops which are a perennial herbaceous and monocotyledonous crop that belongs to the family Musaceae and flowers only once in its life cycle (after 6-10 years) depending on the climate and landrace type (Birmeta et al. 2004). It is a banana-like plant that grows 4-8 $\mathrm{m}$ (sometimes even up to $11 \mathrm{~m}$ ) in height. It is closely related to and has a physical resemblance with the banana plant, as a result of which it is sometimes known as a false banana.

Enset is a multipurpose crop of which every part is utilized; not only for the food of the humans but also for several cultural applications and livestock feed. It is primarily used as humans food, livestock feed, medicinal purposes, ornamental, and as a raw material for industries and construction materials. Being perennial, Enset improves local climate and soil conditions (Shumbulo et al. 2012). Ensete ventricosum is distributed as a wild species in many parts of Sub- Saharan Africa (Maule et al. 2014).

It is the main crop of a sustainable indigenous African system that ensures food security in a country that is food deficient. Ethiopia is one of the centers of diversity and origin for various agricultural crops (IBC 2007). Records suggested that Enset has been grown in Ethiopia for more than 10,000 years (Tsehaye and Kibebew 2006). According to Shumbolo et al. (2012), the cultivation of Enset in Ethiopia was estimated to spread over $67000 \mathrm{~km}^{2}$. Enset planting 
economy is one of the major activities of the agriculture in Southern Nation, Nationalities and People Regional State of Ethiopia.

A landrace is a variable population, which has a local name, lacks formal crop improvement, is associated with the traditional uses, knowledge, habits, and celebrations of the people who developed and continue to grow it (Mercer and Perales 2010). As landraces are morphologically different, farmers can identify and subsequently attach local names to them. Besides, different landraces are recognized to have characteristic adaptation to edaphic factors, reveal individual response to time of seedling, and have typical days to maturity, height, nutritive value, use, and other properties (Tesfaye and Ludders 2003). The loss of diversity of traditional crop landraces or landraces throughout the world has been the subject of considerable concern in the past three decades.

The local diversity of Enset is limited despite the use-value of the crop as food for the majority of the people in Southern Ethiopia. This might have entailed the loss of the existing diversity and associated indigenous knowledge (Tsehaye and Kibebew 2006). Traditional Enset farming systems have so far been studied by agronomists and geneticists, who have attempted to assess the level of morphological diversity found in some parts of the country (Alemu and Sanford 1991). As a species, Enset morphology is highly variable, and although the extent of its variation remains unknown. The basic research questions were: 1/ how many landraces of Enset are cultivated in the study area? 2/ what are the different types of Enset (Ensete ventricosum), and which one is the most commonly used by the local community? $3 /$ is there significant morphological variability within the existing Enset landraces and among landraces grown in different parts of the study area? 4/ what are the different uses of Enset and which parts are used for what purpose? 5/ what cropping systems are used by the local people? 6/ what are the problems or challenges associated with the production of Enset in the study area? and 7/ what kinds of techniques are used by the local community to alleviate the existing challenges of the Enset crop? The purpose of this study is, therefore, to identify the existing Enset landrace diversity, to identify morphological traits diversity among landraces of Enset; to identify threats that affect Enset diversity, and also to identify the associated indigenous knowledge of the people in the study area with the ultimate goal of providing information that will help in constructing the scientific base for the maintenance and sustainable use of the plant.

\section{Materials And Methods}

\section{The study area}

The field sites for this study were Ocha Boba, Nekir, Mari Guta, and Mari Madara kebeles' of the Mareka woreda in Dawuro zone, SNNPRS. Its geographical position is between $37^{0} 0^{0}-37^{0} 1^{0} \mathrm{E}$ latitude and $7^{0} 0^{0}-7^{0} 1^{0}$ longitude (Fig. 1). According to the information obtained from Mareka Woreda Agricultural Office, the area coverage of the study site is 4312.24 hectares. It is situated $438 \mathrm{~km}$ southwest of Addis Ababa, and $326 \mathrm{~km}$ far from Hawassa (the capital of the region). Based on the 2008 census conducted by the CSA, the population of the zone is 453,623 men and 32175 women, with a total of 674898 populations in the zone.

The Dawuro people live a sedentary life based on involving a complex agricultural system using crop rotation and transplanting. Enset is their main staple crop but other cash crops are also grown; which include teff, maize, godare, groundnut, bean, and pea. Animal husbandry is practiced but mainly used for milk supply and dung. The annual maximum temperature of the study area ranges from $22.4-28.3^{\circ} \mathrm{C}$. While the mean annual rainfall of the study area ranges from 976-1404 $\mathrm{mm}$.

\section{Method}




\section{Sampling research sites and informants}

The study sites (Ocha Boba, Nekire, Mari Guta, and Mari Madara kebeles of Mareka Woreda in Dawro zone) were selected based on the areas that have high production of Enset and those Enset landraces which play economic and cultural roles. These study areas were selected by referring to different literature sources, the survey made by CSA (2015) on the area, production of major crops, and using the suitability map of Enset made depending on the data obtained from FAO (1984) on the crops ecological requirements. Information about the production of Enset from agricultural institutions of the study woreda was used. Based on the above selection criteria, the total study was focused by random selection methods, from Ocha kebele 46 households, from Nekire kebele33 households, from Mari Madara kebele 38 households, and from Mari Guta kebele 28 households, or totally 145 households were selected from four kebeles (Table 1). The sample sizes of households were determined by using Yamane's (1967) formula.

$$
\mathrm{n}=\frac{N}{1+N(e) 2}
$$

Where; $\mathrm{N}=$ total population that was studied

$\mathrm{n}=$ required sample size

$\mathrm{e}=$ the precision level which is $(0.08 \%)$ where confidence level is $95 \%$ at

$p= \pm 5$ (maximum variability)

Table 1: Sample kebeles and total sample size of the respondents

\begin{tabular}{|llll|}
\hline Name of kebele's & Total households & Proportion of sample size & Sample size of the households \\
\hline Ocha & 661 & 0.32 & 46 \\
\hline Nekire & 470 & 0.23 & 33 \\
\hline Mari Madara & 541 & 0.26 & 38 \\
\hline Mari Guta & 395 & 0.19 & 28 \\
\hline Total & 2067 & 1 & 145 \\
\hline
\end{tabular}

Ethnobotanical data were collected in order to know the indigenous knowledge of participants or farmers on Enset plants. Different qualitative and quantitative ethnobotanical data collection methods; like field observation, guided field walk, semi-structured interview, and market surveys were used in order to get needed information from the participants. A semistructured interview was used to gather ethnobotanical information on the local name of the crop and landrace, time of cultivation and harvesting, traditional management practices, cropping system, uses and market value of the crop, landraces which survive drought, disease, pest and have short maturity time, planting material exchange system and production constraints and perception of the farmers towards the crop.

For this interview, elderly people, community representatives, official experts were selected from Ocha, Nekire, Mari Madara, and Mari Guta; and from each kebele 46, 33, 38, and 28 individuals, respectively, and a total of 145 individuals were participated (Table 1). The necessary information on the morphology of Enset, how Enset is cultivated, intercropped, used, and marketed were systematically recorded. The local perspectives on dominant crops produced, landscapes, and soil type of the study area were identified through personal observation and discussion with the local experts Market 
survey was undertaken to record the Ensete ventricosum landraces that are sold in the market together with information on market values. This is especially a good method to conserve landraces of Enset that have high economic value.

To characterize the agro-morphological traits of the landraces, all landraces found at the study area were measured by their quantitative and qualitative meanings. Fifteen agronomic descriptors of Enset were evaluated according to the IBPGR (1993) procedure for each landrace (Table 2). There were different morphological and agronomic characteristics that farmers used to identify their landraces in the study area. Of these; the color of pseudo-stem, midrib, leaf, and petiole, time of maturity, disease resistance, yield, leaf dimensions (width and length), and pseudostem length.

\section{Data analysis}

Descriptive statistics were used to analyze data obtained through interviews and guided field walks. The data were analyzed by using SPSS version 16 and an excel spreadsheet, then it was summarized by computing means, standard deviations, ranges, and other tools.

\section{Preference ranking}

In preference ranking, 20 key informants were selected from four kebeles and were asked to arrange a group of items according to a given criterion such as personal preference or importance of a species. Each item was then assigned a value, with the most important or preferred one ranking the highest value, whiles the least important or preferred one ranking the lowest value. Therefore, in this study different use values of Enset species were short-listed and ranked by informants following the procedure explained by Martin (1995).

\section{Direct matrix ranking}

Direct matrix ranking was applied in order to answer the question, which landrace was best for which purpose. Landraces and their purposes were reported by the selected informants. Then, each key informant was asked to rank the landraces for each of the purposes. The values of each landrace were summed up and ranked for each informant, and then finally for the total informants.

\section{Morphological diversity analysis}

Enset landraces diversity analysis including Shannon-Wiener Diversity Index (H) (Shannon and Diversity 1949) and richness and evenness of each study Kebele were analyzed. Shannon- Wiener Diversity Index $(H)$ was used to analyze the phenotypic diversity of Enset depending on the traits that were measured, counted, and recorded. It was calculated using the formula,

$$
H=-\sum_{i=1}^{s} p i \text { linpi }
$$

Where: $\mathrm{S}$ is the number of phenotypic classes for a character and pi is the relative proportion of the total number of entries $(\mathrm{N})$ in the $\mathrm{i}^{\text {th }}$ class (Spellererg and Fedor, 2003). The number of individuals irrespective of their frequencies denotes to richness. Evenness, however, measures how similar the frequencies of the different variants are, with low evenness indicating dominance by one or a few types. Evenness has values between 0 and 1 where 1 indicates the condition where all landraces are equally abundant while 0 indicates that few landraces are more abundant. Evenness is 
calculated as: where $H$ is Shannon-Wiener Diversity Index, $H_{\max }$ is $\ln (\mathrm{N}), \mathrm{N}$ is a total number of landraces. Simpson's diversity index $(1-D)=1-\Sigma(n / N)^{2}$

Where:

$\mathrm{n}=$ the frequency of the $\mathrm{i}^{\text {th }}$ cultivar, i.e., frequency of the cultivar embodied in the $\mathrm{i}^{\text {th }}$ farms in the district, and $\mathrm{N}=$ the total number of farms surveyed in the district

Table 2: Morphological traits measured from Enset landraces of the study area

\begin{tabular}{|c|c|c|}
\hline Character & Code & Qualitative categories or quantitative measures \\
\hline Pseudostem colour & PSC & $\begin{array}{l}1=\text { light green, } 2=\text { deep green, } 3=\text { greenish black } 4=\text { light red, } 5=\text { dark red, } 6=\text { reddish } \\
\text { yellow }\end{array}$ \\
\hline Petiole colour & PC & $\begin{array}{l}1=\text { light green, } 2=\text { deep green, } 3=\text { greenish black } 4=\text { light red, } 5=\text { dark red, } 6=\text { reddish } \\
\text { yellow }\end{array}$ \\
\hline Midrib colour & MC & $\begin{array}{l}1=\text { light green, } 2=\text { deep green, } 3=\text { greenish yellow } 4=\text { greenish red, } 5=\text { light red, } \\
6=\text { dark red, } 7=\text { dark brown }\end{array}$ \\
\hline Leaf colour & LC & $1=$ =light green, $2=$ deep green, $3=$ light red, $4=$ dark red, 5=purple, \\
\hline Kocho quality & $\mathrm{KQ}$ & $1=$ high quality, $2=$ medium quality, $3=$ low quality \\
\hline Bulla quality & $\mathrm{BQ}$ & $1=$ high quality, $2=$ medium quality, $3=$ low quality \\
\hline Fiber quality & FQ & $1=$ high quality, $2=$ medium quality, $3=$ low quality \\
\hline Drought resistances & Dr.R & $1=$ resistance, 2 =venerable \\
\hline Disease resistances & DR & $1=$ resistance, 2 =susceptible \\
\hline Pseudostem length & PL & Meter \\
\hline $\begin{array}{l}\text { Pseudostem } \\
\text { circumstance }\end{array}$ & Psc & Meter \\
\hline Leaf length & LL & Meter \\
\hline Leaf width & LW & Meter \\
\hline Number of leaves & $\mathrm{NL}$ & Number \\
\hline Plant height & $\mathrm{PH}$ & Meter \\
\hline
\end{tabular}

\section{Results}

Out of the total interviewed households $(\mathrm{N}=145), 51$ were females, and 94 were males. An unequal pattern of gender distribution was observed in the specific study sites. Of the total respondents, $16 \%$ of the household heads were less than 35 years old age, while $42 \%$ in the age range between 35-50 and the reset older than 50 years old. It was known from the respondent's responses, females and teenagers have less knowledge about landraces of Enset, even they don't know the name of their landraces. This shows that there is no flow of indigenous knowledge about Enset in the study area. The assessment on the size of the land indicated that the majority (58\%) of the respondents had 1-3 hectares of their own land that are used for farming purposes including the home gardens, and the maximum of land owned by the respondents was 10 hectare of land. 
The size of the Enset farm was found to be smaller than the pieces of land used for harvesting other crops. The largest recorded land cover of Enset was $25 \%$ hectare and on average $13 \%$ hectare of the land in a farm. The size of the land is one of the factors that affect the diversity of the Enset landraces. As the size of the land increases, the diversity of Enset landraces could also be increase. Thirteen percent of the respondents reported 17-20 Enset landraces growing in their yards, while most of the respondents (45\%) grow only four to eight Enset landraces.

A total of 33 landraces were identified from Ocha, Nekri, Mari Madara, and Mari Guta kebeles of the study area based on names and descriptions given by local farmers. Based on the data collected from the informants and agricultural office of the study kebele's, there were no improved Enset varieties used by the farmers of the study area (Fig. 2, Table 3). Depending on the landraces cultivated in the home gardens, the most frequently mentioned descriptors for identification were pseudostem color by $31 \%$ of the respondents, midrib color (17\%), plant size (14\%), and leaf color by $25 \%$ of the respondents were responded.

There were some landraces that have been lost from the study area because of different reasons. These landraces were lost at different times; the majority (52\%) of the farmer's lost their landraces within the last 10-20 years ago. While few (15\%) farmers lost before the last 20 years ago. Lost landraces were known as Lochingiya and Yaka. Fifty-seven percent of farmers replied that production of Enset plants or farmers interest to grow Enset was decreased $33 \%$ said that production of Enset increases and $10 \%$ of the farmers said there is no change in the production of Enset.

Table 3: Diversity of Enset landraces 


\begin{tabular}{|c|c|c|}
\hline S. no & Local name of the landraces & Kebeles \\
\hline 1 & Amiya & Ocha, Nekir \\
\hline 2 & Yesha maziya & Ocha, Nekir \\
\hline 3 & Hoeya & Ocha, Guta \\
\hline 4 & Bothena & Ocha, Nekir, Madara, Guta \\
\hline 5 & Ontha & Ocha, Madara, Guta \\
\hline 6 & Botha maziya & Ocha, Nekir, Guta \\
\hline 7 & Erantiya & Ocha, Nekir, Madara, Guta \\
\hline 8 & Shasha & Ocha \\
\hline 9 & Ankuwa & Ocha \\
\hline 10 & Boza & Ocha \\
\hline 11 & Yaka & Ocha \\
\hline 12 & Badadiya & Ocha \\
\hline 13 & Argama & Ocha \\
\hline 14 & Arkiya & Nekir \\
\hline 15 & Budunthuwa & Nekir \\
\hline 16 & Gena & Nekir \\
\hline 17 & Shododiniya & Nekir \\
\hline 18 & Mataka & Nekir \\
\hline 19 & Aguntha & Nekir \\
\hline 20 & Kuruwa & Guta \\
\hline 21 & Wossa ayfiya & Guta \\
\hline 22 & Keteriya & Guta \\
\hline 23 & Tochinuwa & Guta \\
\hline 24 & Chamerotiya & Guta \\
\hline 25 & Udunthiya & Guta \\
\hline 26 & Shakariya & Madara \\
\hline 27 & Adinona & Madara \\
\hline 28 & Lochinigiya & Madara \\
\hline 29 & Kataniya & Madara \\
\hline 30 & Koshikoshiya & Madara \\
\hline 31 & Wora kana utha & Madara \\
\hline 32 & Babarkiya utha & Madara \\
\hline 33 & Badaluwa & Madara \\
\hline
\end{tabular}


In the study area, some quantitative and qualitative morphological traits of Enset plants were recorded. Most of the qualitative traits of Enset plants recorded were similar in different study kebeles. The original identified 33 Enset landraces were grouped into five clusters based on the morphological traits (pseudostem color, petiole color, leaf color, midrib color, Kocho quality, bulla quality, and fiber quality) and agronomic characters (disease resistance and drought resistance).

Cluster One: This cluster includes the largest number of Enset landraces 13 out of 33 landraces were recorded. Landraces in this group were characterized by having light green pseudostem, deep green leaf, light green midrib, high-quality fiber, and drought and disease resistance. These landracses were Yesha maziya, Hoeya, Amiya, Shasha, Yaka, Bothena, Ontha, Botha maziya, Erantiya, Ankuwa, Boza, Badadiya, and Argama.

Cluster Two: This was well defined on the basis of Kocho, Bulla, and Fiber quality. Landraces in this group provide highquality Bulla, Kocho, and Fiber. Thse are Arkiya Budunthuwa, Gena Shododiniya, Mataka, and Aguntha.

Cluster Three: This cluster includes only two Enset landraces, such as Kuruwa and Wosa ayfiya. The members of this group have dark red pseudostem, deep green leaf medium fiber quality, and vulnerable to drought and diseases.

Cluster Four: This cluster includes four landraces, such as Keteriya, Tochinuwa, Chamerotiya, and Udunthiya. It was well defined on the basis of leaf and resistance to drought and diseases. They had purple leaves and resistant to diseases and drought.

Cluster Five: This cluster comprises landraces having deep red pseudostem, deep red petiole, yellowish-green leaf, and high resistance to disease and drought. This cluster includes eight landraces. These are Shakariya, Adinona, Lochingiya, Kataniya, Koshikoshiya, Babaka, Badaluwa, and Wora kana utha, which means fox's Enset, that is believed by the local people as the seed of the Enset was brought by a fox. It was wild Enset landraces that were cultivated by some of the farmers of the study area (Table 4).

When diversity of Enset was estimated based on the number of landraces (richness) Ocha Kebele (of the Mareka District) showed the largest richness $(H=3.17: D=23.99)$ followed by Nekir Kebele $(H=3.04: D=20.99)$. However, Guta kebele showed the lowest richness $(H=2.56: D=15.9)$. The average number of landrace listed by the farmer was higher in the case of Ocha followed by Nekir, Madara, and Guta, respectively (Table 5).

Table 4: Mean value of the quantitative characters for each cluster of Enset landraces

\begin{tabular}{|c|c|c|c|c|c|c|}
\hline Cluster & $\begin{array}{l}\text { Mean plant } \\
\text { height } \pm \text { SD }\end{array}$ & $\begin{array}{l}\text { Mean pseudo stem } \\
\text { height } \pm \text { SD }\end{array}$ & $\begin{array}{l}\text { Mean pseudostem } \\
\text { circumstances } \pm \text { SD }\end{array}$ & $\begin{array}{l}\text { Mean leaf } \\
\text { width } \\
\pm S D\end{array}$ & $\begin{array}{l}\text { Mean leaf } \\
\text { length } \pm \\
\text { SD }\end{array}$ & $\begin{array}{l}\text { Mean leaf } \\
\text { number } \pm \\
\text { SD }\end{array}$ \\
\hline $\begin{array}{l}\text { Cluster } \\
1\end{array}$ & $6.64 \pm 0.87$ & $2.65 \pm 0.64$ & $1.7 \pm 0.30$ & $0.53 \pm 0.14$ & $3.6 \pm 0.7$ & $14 \pm 4$ \\
\hline $\begin{array}{l}\text { Cluster } \\
2\end{array}$ & $7.7 \pm 0.54$ & $2.98 \pm 1.13$ & $2 \pm 0.36$ & $0.56 \pm 0.15$ & $4.33 \pm 0.3$ & $14 \pm 4.4$ \\
\hline $\begin{array}{l}\text { Cluster } \\
3\end{array}$ & $5.5 \pm 0.282$ & $2.2 \pm 0.28$ & $1.3 \pm 0.14$ & $0.65 \pm 0.07$ & $3.3 \pm 0.6$ & $22 \pm 4.24$ \\
\hline $\begin{array}{l}\text { Cluster } \\
4\end{array}$ & $7.3 \pm 0.72$ & $2.7 \pm 0.46$ & $1.67 \pm 0.49$ & $0.62 \pm 0.06$ & $4.47 \pm 0.2$ & $12 \pm 5.73$ \\
\hline $\begin{array}{l}\text { Cluster } \\
5\end{array}$ & $8.5 \pm 0.897$ & $3.07 \pm 0.64$ & $2.10 \pm 0.37$ & $0.62 \pm 0.15$ & $4.63 \pm 0.6$ & $15 \pm 5.28$ \\
\hline
\end{tabular}


Table 5: Landrace diversity in study kebeles expressed as Richness (C), Evenness (E), Simpson (D), and Shannon (H区) diversity indices

\begin{tabular}{|llll|}
\hline Kebele & Richness $(\mathrm{C})$ & Diversity index $(\mathrm{H})$ & Evenness \\
\hline Ocha & 24 & 3.18 & 1 \\
\hline Nekir & 21 & 3.04 & 1 \\
\hline Guta & 13 & 2.56 & 1 \\
\hline Madara & 19 & 2.94 & 1 \\
\hline
\end{tabular}

In Ocha kebele, the most dominant Enset landraces were Amiya followed by Hoeya, Boza, Botha maziya, respectively, while in Nekir kebele dominant landraces were Ontha, Yaka, and Adinona. In Guta kebele Shasha, Erantiya, Ankuwa, Gena, Budunthuwa and Kuruwa were the dominant one. The dominant landraces in Madara kebele were Keteriya, Arkiya, Argama, Mataka, and Shododiniya, respectively. However, in Ocha kebele, about 24 different Enset landraces were identified. Out of these the major and widely used landraces were 10; such as Amiya, Yeshimaziya, Boza, Hoeya, Bothena Ontha, Ankuwa, Shasha, Yaka, and Botha Maziya, respectively (Table 6).

Table 6: Direct matrix ranking of ten landraces of Mareka district against eight properties with values 3=highest, 2=medium, and $1=$ lowest

\begin{tabular}{|c|c|c|c|c|c|c|c|c|c|c|}
\hline \multirow[t]{2}{*}{ Properties } & \multicolumn{10}{|c|}{ Landraces } \\
\hline & Amiya & $\begin{array}{l}\text { Yesha } \\
\text { maziya }\end{array}$ & Boza & Hoeya & Bothena & Ontha & Ankuwa & Shasha & Yaka & $\begin{array}{l}\text { Botha } \\
\text { maziya }\end{array}$ \\
\hline Yield & 1.40 & 1.40 & 2.8 & 2.40 & 1.40 & 2.60 & 2.25 & 2.50 & 1.40 & 2.90 \\
\hline $\begin{array}{l}\text { Maturity } \\
\text { time }\end{array}$ & 1.60 & 1.60 & 1.5 & 2.20 & 2.80 & 2.60 & 2.60 & 3.00 & 1.4 & 1.25 \\
\hline Taste & 2.50 & 1.40 & 1.8 & 1.50 & 1.25 & 2.25 & 2.50 & 1.50 & 2.80 & 2.80 \\
\hline $\begin{array}{l}\text { Drought } \\
\text { tolerance }\end{array}$ & 1.25 & 2.20 & 2.6 & 2.50 & 2.50 & 1.40 & 2.80 & 1.5 & 1.6 & 3.00 \\
\hline $\begin{array}{l}\text { Disease } \\
\text { resistance }\end{array}$ & 2.60 & 2.30 & 2.8 & 2.25 & 2.50 & 2.60 & 2.80 & 1.12 & 1.4 & 2.80 \\
\hline $\begin{array}{l}\text { Kocho } \\
\text { quality }\end{array}$ & 1.60 & 1.25 & 2.4 & 2.50 & 2.60 & 2.90 & 2.60 & 1.40 & 1.75 & 2.80 \\
\hline $\begin{array}{l}\text { Bulla } \\
\text { quality }\end{array}$ & 1.40 & 1.40 & 2.5 & 2.40 & 2.50 & 2.90 & 2.60 & 2.40 & 2.6 & 2.90 \\
\hline $\begin{array}{l}\text { Fiber } \\
\text { quality }\end{array}$ & 2.60 & 2.25 & 3.0 & 1.90 & 2.50 & 2.60 & 2.60 & 1.60 & 1.5 & 2.60 \\
\hline Total & 14.75 & 13.75 & 19.4 & 17.8 & 19.15 & 19.80 & 20.75 & 15.02 & 14.45 & 21.05 \\
\hline Rank & $8^{\text {th }}$ & $10^{\text {th }}$ & $4^{\text {th }}$ & $6^{\text {th }}$ & $5^{\text {th }}$ & $3^{\text {rd }}$ & $2^{\text {nd }}$ & $7^{\text {th }}$ & $9^{\text {th }}$ & $1^{\text {st }}$ \\
\hline
\end{tabular}

All Enset growing farmers of the study area are growing Enset plants at their home garden. Enset was grown as a sole crop or intercropped with chat, coffee, and different fruits like apple, mango, avocado, and border cropped. Forty percent of the respondents grow Enset as a sole crop, 50\% intercropping, and the rest 10\% border cropped (Table 7 and Fig. 2).

Table 7: Cropping system practiced in the study area 


\begin{tabular}{|c|c|c|c|}
\hline $\begin{array}{l}\text { Cropping } \\
\text { system }\end{array}$ & $\begin{array}{l}\text { Percentage of } \\
\text { respondents }\end{array}$ & $\begin{array}{l}\text { Plants grow in } \\
\text { association }\end{array}$ & Use of cropping system \\
\hline $\begin{array}{l}\text { Sole } \\
\text { cropping }\end{array}$ & $40 \%$ & - & $\begin{array}{l}\text { To control disease and pest spread and to minimize } \\
\text { food and water competition }\end{array}$ \\
\hline Intercropping & $50 \%$ & $\begin{array}{l}\text { Coffee, chat, mango, } \\
\text { avocado, apple, guava, }\end{array}$ & To use the land efficiently \\
\hline $\begin{array}{l}\text { Border } \\
\text { cropping }\end{array}$ & $10 \%$ & $\begin{array}{l}\text { Vegetables like } \\
\text { cabbage and tomato }\end{array}$ & $\begin{array}{l}\text { To protect susceptible crops from disease and pest } \\
\text { attack and also to use Enset as a windbreak }\end{array}$ \\
\hline
\end{tabular}

Most (57\%) of the informants have got their Enset planting materials by producing the Enset planting materials by themself, (34\%) by informal exchange with neighbors and relatives, and $9 \%$ by purchasing from others. All farmers of the study area select their planting material for the next season based on different traits of the landraces (such as the size of the landrace, Kocho, and Bulla quality, Fiber quality, uses of landraces, and disease, and pest resistance of the landraces.

Enset is a multipurpose staple crop used for different purposes. In the study area, farmers use Enset for household consumption, such as (food, medicinal purposes, fiber, and feed) and as an income generation for their livelihood. Out of the total informants, $80 \%$ were used Enset only for household consumption while $20 \%$ of them were used a quarter of their Enset products as a source of income generation.

Enset plant is used as a source of major food staff utilized in different forms by the local people for their daily consumption, and it is a means of subsistent livelihood of the community since several years ago. All the Enset landraces prepared in different forms and utilized as food by the local people (Table 8).

Table 8: Food uses of Enset and method of preparation

\begin{tabular}{|lll|}
\hline $\begin{array}{l}\text { Landraces } \\
\text { name }\end{array}$ & $\begin{array}{l}\text { Types } \\
\text { of } \\
\text { food }\end{array}$ & Methods of preparation \\
\hline $\begin{array}{l}\text { All the } \\
\text { landraces }\end{array}$ & Kocho & $\begin{array}{l}\text { Scrapped leaf sheath and grated corm mixed, wrapped in Enset and stored underground until } \\
\text { fermented }\end{array}$ \\
\hline $\begin{array}{l}\text { All the } \\
\text { landraces }\end{array}$ & Bulla & $\begin{array}{l}\text { Scrapping the leaf sheath peduncle, and grated corm into a pulp, and squeezing liquid } \\
\text { containing starch from the pulp allowing the resultant starch to concentrate into white powder } \\
\text { and rehydrating with water }\end{array}$ \\
\hline
\end{tabular}

In the study area, there are eight landraces that were reported for use to treat various diseases; they were Arkiya, Lochingiya, Badadiya, Argama, Kataniya, Mataka, Aguntha, and Boza. In the study area, there are eight landraces that were reported for use to treat various diseases; they are Arkiya, Lochingiya, Badadiya, Argama, Kataniya, Mataka, Aguntha, and Boza. The name of the enset landraces, parts used for treatment, kind of disease and/or injury treated, and the way of their preparation listed below in Table 9.

Table 9: Enset landraces, part/s used for treatment, type of disease and use as medicine, and their preparation methods 


\begin{tabular}{|c|c|c|c|}
\hline $\begin{array}{l}\text { Name of } \\
\text { the } \\
\text { landrace }\end{array}$ & Parts used & Used to treat the disease or injury & Methods of preparation \\
\hline Arkiya & Corm & $\begin{array}{l}\text { To dried abscess; for normal functioning of the } \\
\text { body; to cure cough }\end{array}$ & $\begin{array}{l}\text { The corm boiled and eaten with } \\
\text { milk }\end{array}$ \\
\hline Lochingiya & Corm & $\begin{array}{l}\text { Used to join the broken body (bone), for lung } \\
\text { disease and cough, to harden the damaged } \\
\text { organ }\end{array}$ & $\begin{array}{l}\text { The corm boiled and eaten with } \\
\text { cheese }\end{array}$ \\
\hline Badadiya & $\begin{array}{l}\text { Corm and } \\
\text { pseudostem }\end{array}$ & $\begin{array}{l}\text { To repair and soften the broken body (bone) } \\
\text { initiate milk production for mammary gland of } \\
\text { the women }\end{array}$ & $\begin{array}{l}\text { The corm sliced and boiled and the } \\
\text { starchy powder bulla are eaten } \\
\text { with milk }\end{array}$ \\
\hline Kataniya & $\begin{array}{l}\text { Corm and } \\
\text { pseudostem }\end{array}$ & For dried the wound of human and cattle & $\begin{array}{l}\text { Corm boiled and given to cattle } \\
\text { with salt }\end{array}$ \\
\hline \multirow[t]{2}{*}{ Boza } & \multirow{2}{*}{$\begin{array}{l}\text { Corm and } \\
\text { pseudostem }\end{array}$} & For fattening of livestock & \multirow{2}{*}{$\begin{array}{l}\text { Corticated and given to the } \\
\text { livestock }\end{array}$} \\
\hline & & For the normal functioning of the body & \\
\hline Argama & Corm & For the normal functioning of the body & $\begin{array}{l}\text { The corm boiled and eaten with } \\
\text { milk }\end{array}$ \\
\hline Aguntha & Corm & $\begin{array}{l}\text { Used to join the broken body (bone), for lung } \\
\text { disease and cough, to harden the damaged } \\
\text { organ }\end{array}$ & $\begin{array}{l}\text { The corm boiled and eaten with } \\
\text { cheese }\end{array}$ \\
\hline Mataka & $\begin{array}{l}\text { Corm and } \\
\text { pseudostem }\end{array}$ & $\begin{array}{l}\text { To repair and soften the broken body (bone) } \\
\text { initiate milk production for mammary gland of } \\
\text { the women }\end{array}$ & $\begin{array}{l}\text { The corm sliced and boiled and the } \\
\text { starchy powder bulla are eaten } \\
\text { with milk }\end{array}$ \\
\hline
\end{tabular}

Preference ranking on the use-value of Enset by the key informants showed that Enset primarily uses as a source of food by the local people which is followed by the use for medicinal purposes, and the least use as a means of income generation. Preference ranking on the use-value of Enset in the study area indicated from number $1=$ the least useful up to $5=$ the most useful in increasing order (Table 10).

Table 10: Preference ranking on the use-value of Enset

\begin{tabular}{|llllll|}
\hline Data collection kebele & Food & Feed & Medicinal & Fiber & Income generation \\
\hline Ocha & 5 & 4 & 3 & 3 & 2 \\
\hline Nekir & 5 & 4 & 2 & 4 & 3 \\
\hline Guta & 5 & 3 & 3 & 2 & 1 \\
\hline Madara & 5 & 2 & 2 & 3 & 2 \\
\hline Total & 20 & 13 & 10 & 12 & 8 \\
\hline Rank & $1^{\text {st }}$ & $2^{\text {nd }}$ & $4^{\text {th }}$ & $3^{\text {rd }}$ & $5^{\text {th }}$ \\
\hline
\end{tabular}

Enset has unique characters that make it preferable to the other crops in the study area. Out of these properties of Enset, farmers of the study area mentioned the major one. These were its socio-cultural significance, high household material culture benefits, flexibility in farming systems as an intercrop with annual and perennial crops, drought tolerance, suitability for preparation of staple and high social value dishes, or traditional food, storability of Enset products for long periods (stay without spoiled for a long period of time), the possibility of harvesting at any time of the year, use for 
integration of the crop-livestock system, use for the production of high-quality fiber, use as water source from pseudostem, use as firewood source mainly from dried plant parts, generating income from sales of prop gules, processed food products, and fiber, and medicinal purposes for humans and livestock ailments make Enset to be more preferable to the other crops.

Out of the total interviewed participants, $48 \%$ responded, Enset production and productivity is affected by several biotic and abiotic influences and $22 \%$ of the respondents answered, Enset diseases caused by bacteria, fungi, nematodes, as well as pests such as the attack from mole rats and porcupines are among the many other factors causing less productivity. However, $30 \%$ of the farmers in the study area identified Enset wilting diseases, Enset corm rot, and Enset leaf sheath rot as great problems of Enset products (Fig 4).

In the study area, Enset production activities are the responsibilities of both females and males. However, the majority of the activities are done by females except that of preparing seedlings, digging the hole, planting, and uprooting the Enset during the harvesting period which is done male-only. Without the involvement of women, the cultivation of Enset is meaningless in the study area. In the study area, the role of women in the Enset production was very high, however on the maintenances of landraces they are less aware, even they do not know the name of the landraces, and they asked their husbands during the need.

Markets were there, in the study area, however, the existing market was not strong, with few buyers and farmers have poor access to market information on Enset products. Enset was thought of by the community of the study area as women's property and the only person who decide on Enset are women. They only use Enset plants for income generation by selling to the market if they have enough products for their annual consumption. A market survey was undertaken in five markets found in the study area, only one of them found in the Nekir kebele, and the rest found in the capital town of the district. The names of the markets are Sunday market, Monday market, Wednesday market, Friday market, and Saturday market. The price of Enset products was slightly cheap in all of the markets.

\section{Discussion}

The Ensete ventricosum is found at the greatest frequency with different landraces. According to informant report, Enset was very diverse ranging from 4 to more than 20/farm on this study area. Each farmer owns the various number of Enset landraces in his/her farmland. The landrace identification mechanism used by farmers on different study kebeles has no significant difference. They identified each landrace by using different morphological traits like pseudostem, petiole, and midrib color, and plant size. The traditional identification mechanism used by the farmers of this study area is similar to the way of identification used by the Sidama zone and Wolaita Zone (Magule et al. 2014; Assefa and Fitamo 2016). In this study, the identified landraces found to differ related to morphology, adaptation to diseases and pests, drought resistance, maturity time, and uses. In the case of maturity time, almost all landraces of the study area have the same maturity time, which (long and stays 7-9) years except Yaka and Botha Maziya which have short maturity time (4-5 years).

Enset is a drought and disease-resistant crop. However, there were differences in the adaptation to drought and disease between the landraces. Two of the landraces Botha maziya and Boza were the most resistant landraces of the study area and the landraces which are used for medicinal purposes such as Lochingiya, Badadiya, Kataniya, were the most susceptible landraces of the study area. Botha maziya and Ontha are known for their quality of Kocho. The difference of landraces was based on the yield, such as Boza, Hoeya and Shasha are high yielding landraces, however, have a low quality of Kocho and Bulla.

According to the results, Enset is cultivated by every farming household in the study area, and it is the crop of choice for the community, however, the majority of farmers, responded that cultivation of Enset falling from time to time similar to 
studies conducted in Gedebano Gutazer welene district by Kedir Abdella (2017). As a result of this, at present due to the food shortage, Enset products are consumed immediately after harvest. That is, they do not store Enset products for many years as they did in the past. Increasing demand to engage in the production of other crops was one of the reasons that accounted for the decreasing trend of Enset production. This is because of population growth and shortage of land which leads them to food shortage and they forced to grow short-season crops instead of Enset. This agrees with recent reports on the vulnerability of agricultural systems and agro-biodiversity in Southern Ethiopia by Abebe and Eshetu (2009). The difficulty of the processing system was also the one and alarming reason for the reduction of Enset production. This result was similar to studies of Alemu and Sanford (1991) that were done in the North Omo zone Ethiopia.

The dendrogram obtained from Ward's (1963) hierarchical cluster analysis grouped 33 identified Enset landraces into five clusters based on the qualitative characters taken. This clustering helps to know landraces that have related characters. Based on the cluster means, variation of mean values among the cluster were recorded for different quantitative characters. The mean plant height of cluster five and cluster two was significantly different by having the highest mean and cluster three have a significant difference in having the smallest mean of plant height. A reasonable amount of morphological variation was displayed for the traits evaluated in this study. This finding is similar to Yemataw et al. (2014) results who reported a wide range of variations in different characters of enset. Variation, as it is expressed by morphological analysis was reasonable among the Enset landraces and variation of Enset landraces, of which farmers were little aware is significant in their recognition of variation and therefore it plays a role in their selection and maintenance of the overall variability.

In this study 33 Enset landraces were identified. Similar studies conducted on Enset landraces, in the Gurage zone by Zerihun reported that a total of 32 locally known landraces were identified. Moreover, the study of Yemataw et al. (2014) and Zeberga et al. (2014) on Enset landraces in the Gurage zone, Ethiopia indicated that 63 locally known Enset landraces were recorded. The variations in the number of Enset landraces recorded in different parts of the country might be due to the difference in the number of sampled zone selected for the study. The number of Enset landraces (richness) per household varies from Kebele to kebele. Ocha has the highest landrace richness, Shannon diversity index, and evenness, while Guta Kebele has the lowest. A high diversity index suggests that the area is not dominated by one or two landraces rather by a number of successful landraces. A low value for the index diversity suggested that only a few successful landraces or the kebele are dominated by a limited number of landraces. In these kebeles majority of the landraces were replaced by landraces that are disease resistant known as Boza since the kabele was highly affected by diseases and the kebeles were dominated by Boza. Applying these concepts at the scale of traditional landraces requires prior determination of the identity of the landraces (Jarvis et al. 2008). Evenness, also measures how similar the frequencies of the different variants are, with low evenness indicating dominance by one or a few types. There was no significant difference in the number of landraces at the kebele level. The number of landraces increases as the number of surveyed household increases, and become constant as a number of households continuously increase.

In the study area, farmers are cultivating Enset crops in their home gardens. A similar study by Magule et al. (2014), which was done in Wolaita, Southern Ethiopia, indicated that every farming household cultivates Enset in its home garden. In the study area Enset cultivation system, planting and harvesting time have no significant difference among the study kebeles. Enset was the major crop growing at the home garden of the farmers in the study area, which was followed by chat and coffee crops. In the study area, planting of Enset was done from the month of October to December, and planting was occurred by the male-only. The study of Shumbulo et al. (2012), conducted in Offa District, Wolaita zone indicated that Enset cultivation needs careful attention.

Farmer did not plant suckers directly in the permanent field. They transplanted Enset suckers from one to four times until it gets to the permanent field. Enset has different local names as it indicates the growth stage of Enset. The first stage is

Page $14 / 21$ 
known as Haluwa. This is a younger stage of sucker usually grown in mass from a planted half corm. It takes one year to be transplanted to the next stage called Shaka'. Shaka' is the stage when separated sucker and planted to the individual hole and allowed to stay for two years depending on management.

The Garduwa is transplanted into wider spacing so as to allow vigorous growth of sukers for at least two years. From this onwards, the most vigorous suckers are finally transplanted into a permanent field as Woga Utha. Enset needs series fallow up after planting at each step, sanitation, hand weeding, and application of manure are the common practice done by the farmers.

In the present study area, Enset had been grown mainly as a sole cropping system, and some other cropping systems; such as border cropping, and enter cropping were practiced by the local farmers. Enter cropping practiced in all study kebeles by some of the informants. They used this cropping system for efficient use of lands and they got many products at the same time for the market, and for their children and the whole family subsistence. The crop planted enter crop with enset were chat, coffee, and different types of fruits like mango and avocado.

In Ethiopia, Enset is produced mainly as a source of food for the family's subsistence (Yemataw et al. 2012). In this study area, Enset is also mainly produced as a source of food, and also uses for the medicinal purpose threatening ailments, feed for livestock, fibber for house construction and material culture, and as a means of income generation. Enset was not produced purposively for fiber by the local people. Fibber and leaves of Enset plants are the by-products of which are used by the local people as a raw material for making different household materials and construction of houses. This study goes in line with the work of Abraham Shumbolo et al. (2012) done at Offa district, Wolaita zone, Southern Ethiopia, in which Enset is used. In their study area, they are mainly used as a source of food for their livelihood. For instance; corms, pseudostem, and stalk of the inflorescences were used in the form of ferment of the scraped leaf sheaths and grated corm mixed (Kocho), a squeeze of the scraped leaf sheath, peduncle, and grated corm (bulla), and boiled Enset corm (Amicho). In this study, the different parts of Enset; such as a corm, pseudostem, and leaf were used for medicinal purposes to treat human and livestock ailments. The local farmers replied that there was no known recommended dosage for the medical treatment of the human and livestock, and they give the treatment simply until it becomes a cure from the disease.

\section{Conclusions}

During the present study, 33 Enset landraces were identified from all the study kebeles with different local names. The local people are using these Enset landraces for different purposes. They used mainly as a source of food, which was followed by animal feed, medicine, and fiber, and only a few of them use it as a means of income generation. This research confirms that the role that the local farmers play in the maintenance of their Enset landraces was high. Farmers have their own indigenous Enset planting material selection, multiplication, and management system. The result of this study indicated that, even if intercropping and border cropping is practiced in the study area, the sole cropping system was more preferable for more production and quality products. The identified Enset landraces have morphological variability by plant height, pseudostem (color, length, and circumstances), midrib color, leaf dimension, disease and drought resistance, Kocho quality, Bulla quality, and fiber quality. In addition to the farmer characterization, measurement was done for some quantitative and qualitative traits. Although some characters were the same throughout the study area, while some other characters like plant height, pseudostem (height and circumstance), and leaf dimensions are shown some differences. Based on this measurement, Enset landraces of the study area classified into five clusters depending on their similarity. This clustering of similar landraces together and knowing morphological variation among landraces helps the farmers for their selection and maintenance of their landraces. Generally, the result of this study indicated that the Mareka district of the Dawro zone is rich in having different Enset landraces, culture, and indigenous knowledge on Enset production and maintenance, however, there were some Enset landraces that had been lost due to

Page $15 / 21$ 
different factors like shortage of land, climate change, replacement with high-quality landraces and a reduction of Enset production in the study area. From those of the aforementioned factors, the replacement of these landraces with high quality and disease-resistant landrace was the major. As a result of these factors, not only the reduction in the landraces but also the loss of some landraces and their habitat will ultimately cause the loss of the knowledge, services, and cultural values about Enset crops that might bring a cumulative effect in the future.

\section{Recommendations}

Based on the aforementioned conclusion, the following recommendations are forwarded:

- Promoting a better technology for the Enset processing system is vital.

- Expanding Enset landraces cultivation culture in all parts of the country is crucial as a food security and subsistence livelihood.

- A further study on propagation and morphology of Enset including seed and flower of the identified landraces for further identification of landraces is required.

- Extension service and training have to be given by the concerned bodies for the local farmers on the different production constraints like that of other crops.

\section{Abbreviations}

- CSA: Central Statically Agency of Ethiopia

- FAO: Food and Agricultural Organisation

- IBC, Institute of Biodiversity Conservation

- IBPGRI: International Board for Plant Genetic Resources

- SNNPRS: Southern Nations Nationalities, and People Regional State

\section{Declarations}

\section{Ethics approval and consent to participate}

This study conducted in accordance with the declaration of Helsinki that provides guidance for the researcher to protect research subjects. The study was approved by the Institutional Research Review Board (IRB) of Wolaita Sodo University. Consent to participation is not applicable to this article.

\section{Consent for publication}

All authors agreed to the public this original research work

\section{Availability of data and material}

Data sharing not applicable to this manuscript as no datasets were generated or analyzed during the current study.

\section{Competing interests}

The authors declare that they have no competing interests.

\section{Funding}


This research did not receive any specific grant from funding agencies in the public, commercial, or not-for-profit sectors.

\section{Authors' contributions}

All authors contributed to the study conception and design. Material preparation, data collection, and analysis were performed by Newarinesh Feleke and Wondimagegnehu Tekalign. The first draft of the manuscript was written by Newarinesh Feleke and all authors commented on previous versions of the manuscript. All authors read and approved the final manuscript.

\section{References}

Abebe T, Eshetu G. 2009. Analysis of vulnerability and determinants of Enset production in Wolaita, Southern Ethiopia. Acta Horticulturae, 806, 663-668.

Alemu K, Sandford S. 1991. Enset in North Omo Region. Farmers' Research Project (FRP). FARM Africa. Addis Ababa. Ethiopia.

Assefa A, Fitamo D. 2016. Diversity of Enset landraces (Ensete ventricosum Welw Cheesman) in Aleta Chuko District, Sidama Zone, South Nation Nationality People and Regional State, Ethiopia. Journal of Plant Sciences, 4(1), 1-7.

Birmeta G, Nybom H, Bekele E. 2004. Distinction between wild and cultivated enset (Ensete ventricosum) gene pools in Ethiopia using RAPD markers. Hereditas, 140, 139-148.

CSA. 2015. Report on area and production of major crops (Private peasant holdings, meher season).Volume one. The Federal Democratic Republic Of Ethiopia (FDREP). Addis Ababa, Ethiopia.

FAO. 1984. Land Evaluation: Part Three. Crop environmental requirements. Assistance to land use planning, Ministry of Agriculture, Addis Ababa, Ethiopia.

Hildebrand E. 2001. Morphological characterization of domestic vs forest-growing Ensete ventricosum Welw Cheesman, Musaceae, in Sheko district, Bench-Maji Zone, southwest Ethiopia. Biodiversity research in the horn of Africa region. Biologiske Skrifter, 54, 287-309.

IBC. 2007. Ethiopia secondary Report on the state of PGRFA to FAO.

IBPGRI. 1993. Diversity for development. International Plant Genetic Resources Institute, Rome, Italy.

Jarvis D I, Antony H D, Pham H C, Panduro L C, Moreno L L, Gyawali S, Tanto T, Sawadogo M, Mar I, Sadik M. 2008. A global perspective of the richness and evenness of traditional crop variety diversity maintained by farming communities.

Magule T, Tesfaye B, Catellani M, Enrico M. 2014. Indigenous knowledge, use and on-farm management of enset (Ensete ventricosum Welw Cheesman) diversity in Wolaita, Southern Ethiopia. Journal of Ethnobiology and Ethnomedicine, 10, 118.

Martin J G. 1995. Ethnobotany, A methods manual. Chapman \& Hall, London. McCabe, J.T., (1996). The Role of Livestock in the Enset Cultivation System: A Review of the Literature. Agricultural Research Center, Hwassa, Mimeo.

Mercer K L, Perales H R. 2010. Evolutionary response of landraces to climate change in centers of crop diversity. Evolutionary Applications, 3, 480-493.

Shannon C E, Weaver W. 1949. The mathematical theory of communication, Vol. 1. Univ. Illinois Press, Urbana, Pp. 17. 
Shumbolo A, Gecho Y, Tora M. 2012. Diversity Challenges and Potentials of enset (Ensete ventricosum) Production: In case of Offa district, Wolaita zone, Southern Ethiopia. Food Science and Quality Management, 7, 24-31.

Spellerberg I F, Fedor P J. 2003. A tribute to Claude Shannon and a plea for more rigorous use of species richness, species diversity and the Shannon-Wiener Index. Global Ecology and Biogeography, 12, 177-179.

Tesfaye B, Ludders P. 2003. Diversity and distribution patterns of enset landraces in Sidama, Southern Ethiopia.

Tsehaye Y, Kebebew F. 2006. Diversity and cultural use of Enset (Enset ventricosum, Welw. Cheesman) in Bonga in situ Conservation Site, Ethiopia. Ethnobotany Research and Applications, 4,147-157.

Ward J H. 1963. Hierarchical groupings to optimise an objective function. Journal of the American Statistician Association, 58, 236-244.

Yemane T. 1967. Statistics, an introductory analysis, 2nd edn. Harper and Row, New York.

Yemataw Z, Mohamed H, Diro M, Addis T, Blomme G. 2014. Ethnic-based diversity and distribution of enset (Ensete ventricosum) clones in southern Ethiopia. Journal of Ecology and the Natural Environment, 6(7), 244-251.

Yntiso G. 1996. Economic and socio-cultural significance of enset among the Ari of southwest Ethiopia.

Zeberga A, Yemataw Z, Musemil S, Sinebo W, Ambachew D. 2014. On Farm Cultivar Diversity of Enset (Ensete ventricosum) in Southern Ethiopia. JAD, 4, 55-60.

\section{Figures}




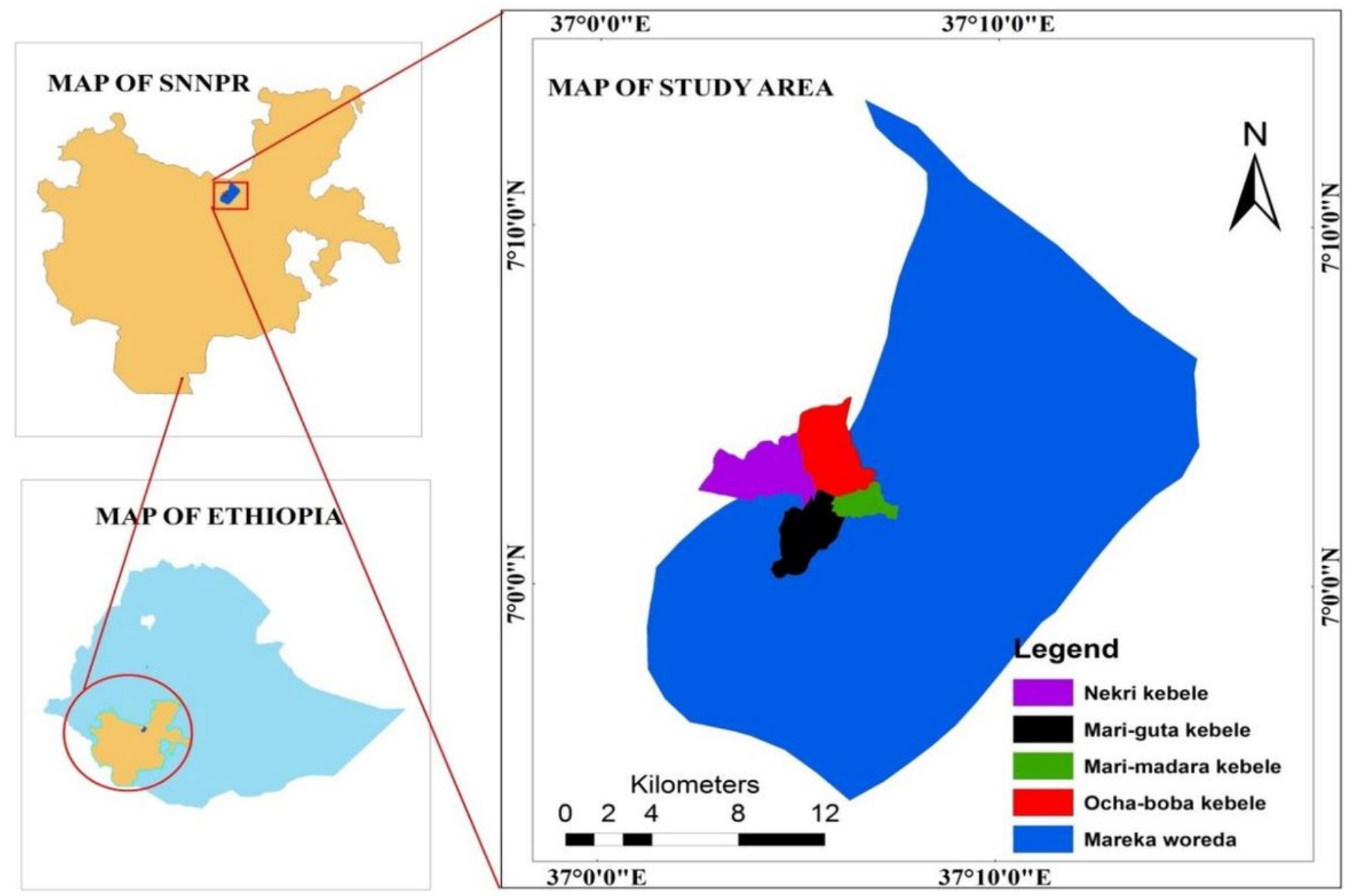

Figure 1

Map of the study area 


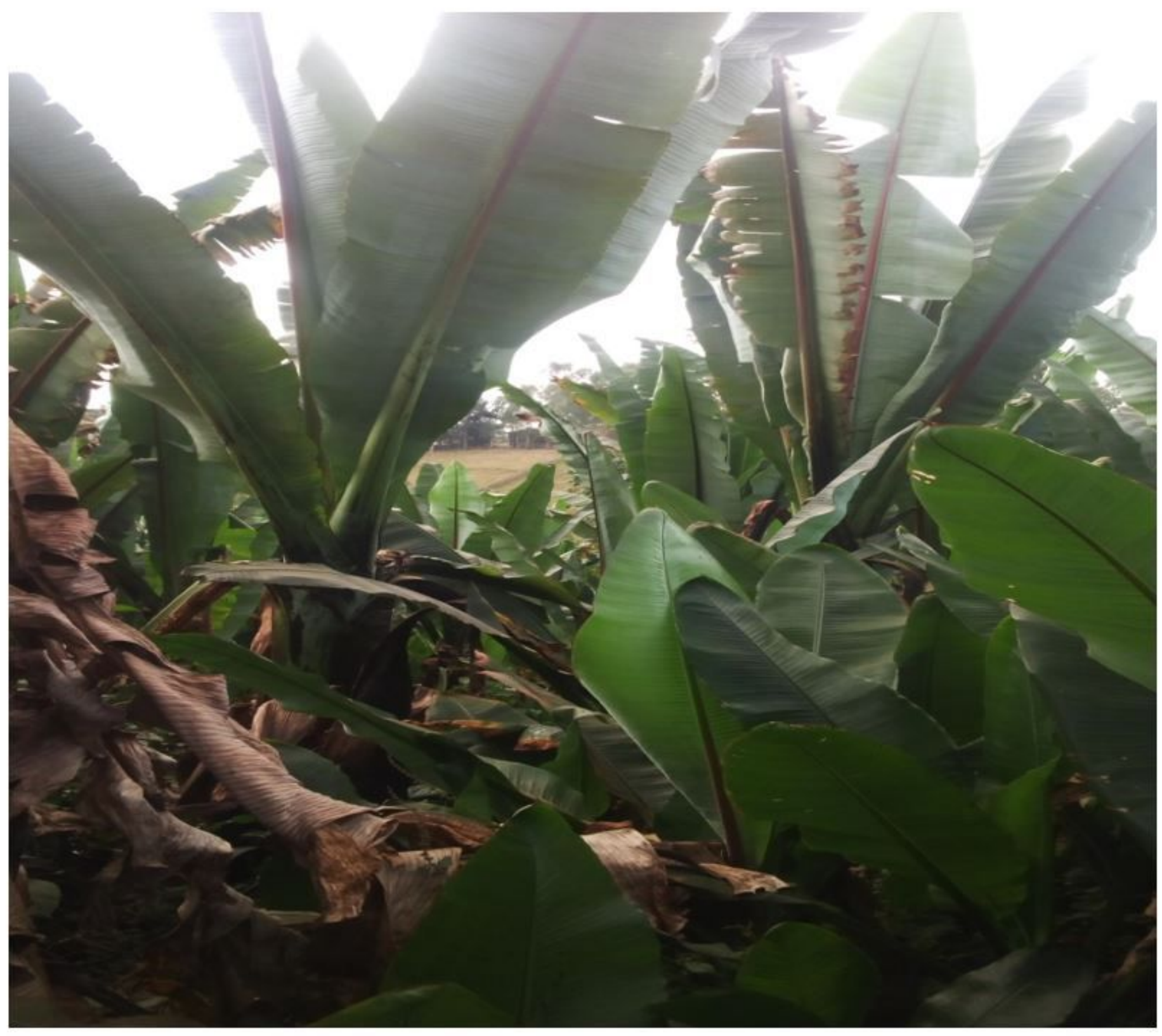

Figure 2

Morphological diversity of Enset 


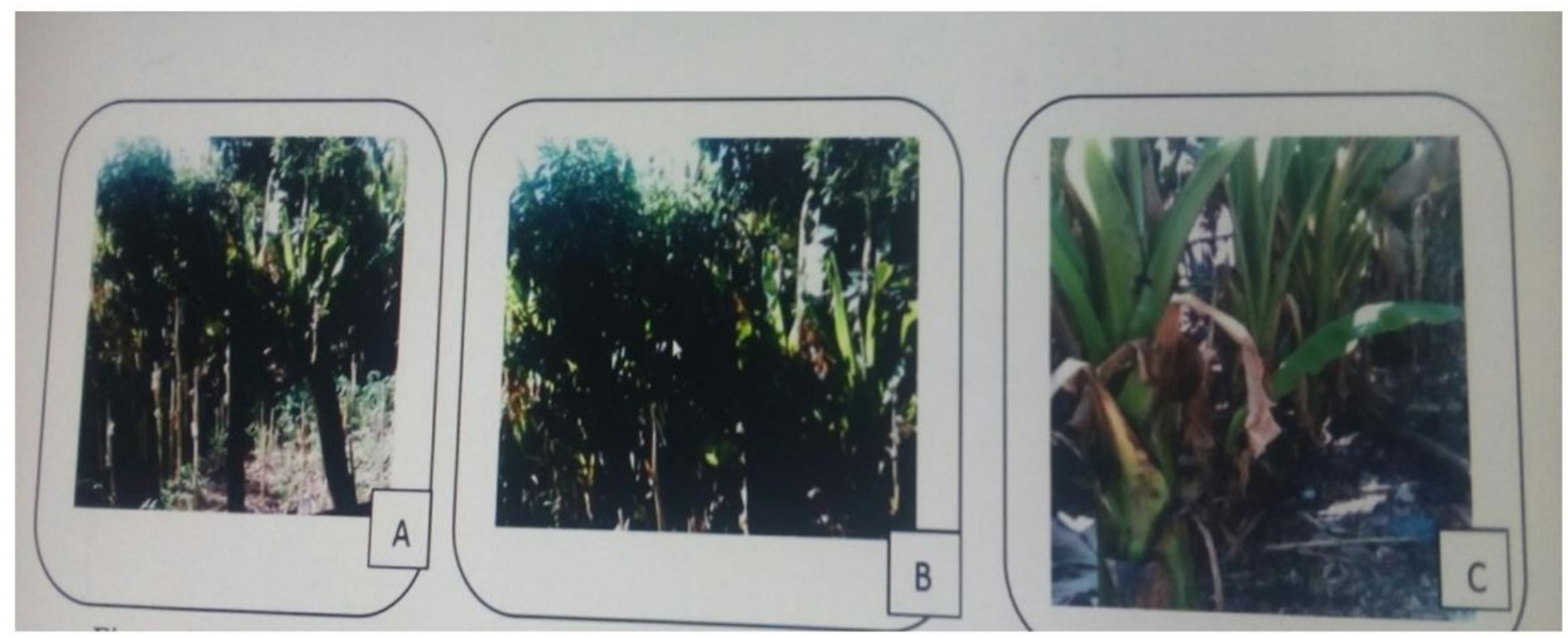

Figure 3

Cropping system of Enset in the study area (Note: $A=$ Border cropping, $B=$ Intercropping, and $C=$ sole cropping)

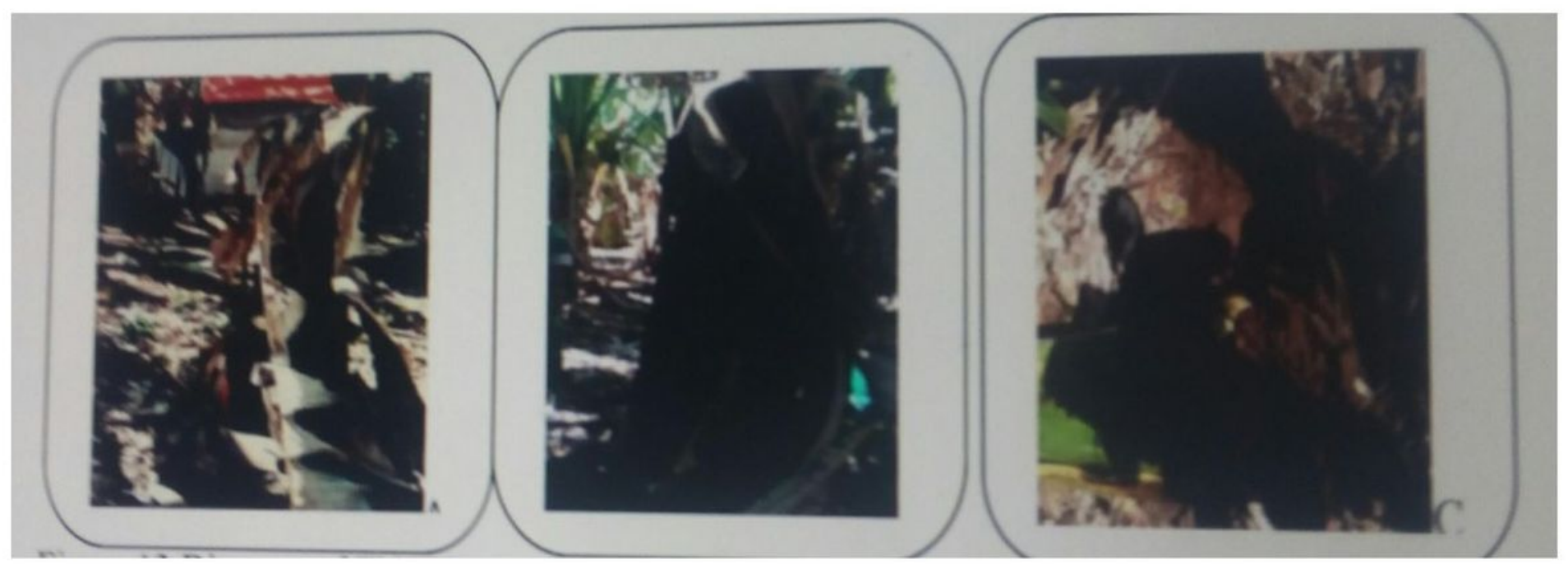

Figure 4

Constrains of Enset production 